\title{
Penerapan Metode RAD Pada Sistem Informasi Layanan Umroh Di PT. Galang Saudi Tourism Jakarta Berbasis Website
}

\author{
Agus Salim ${ }^{1}$, Jefi Jefi ${ }^{2}$, Baginda Oloan Lubis ${ }^{1, *}$, Jaka Atmaja ${ }^{3}$, Firstianty Wahyuhening \\ Fibriany ${ }^{1}$ \\ ${ }^{1}$ Sistem Informasi; Universitas Bina Sarana Informatika; JI. Kramat Raya No. 98, Jakarta Pusat, \\ Telp. (021) 8000063; e-mail: agus.salim@bsi.ac.id, baginda.bio@bsi.ac.id, \\ firstianty.fbr@bsi.ac.id \\ 2 Teknologi Informasi; Universitas Bina Sarana Informatika; Jl. Kramat Raya No. 98, Jakarta \\ Pusat, Telp. (021) 8000063; e-mail: jefi.jfi@bsi.ac.id \\ 3 IImu Komunikasi; Universitas Bina Sarana Informatika; JI. Kramat Raya No. 98, Jakarta \\ Pusat, Telp. (021) 8000063; e-mail: jaka.jaj@bsi.ac.id \\ *Korespondensi: e-mail: baginda.bio@bsi.ac.id
}

Diterima: 28 April 2021; Review: 03 Mei 2021; Disetujui: 31 Mei 2021

Cara sitasi: Salim A, Jefi J, Lubis BO, Atmaja J, Fibriany FW. 2021. Penerapan Metode RAD Pada Sistem Informasi Layanan Umroh Di PT. Galang Saudi Tourism Jakarta Berbasis Website. Bina Insani ICT Journal. Vol. 8 (1): 1-11.

\begin{abstract}
Abstrak: Sebagai penyedia jasa layanan umroh, PT. Galang Saudi Tourism Jakarta menyediakan bebrapa paket pilihan umroh yang dibutuhkan oleh jamaah. PT. Galang Saudi Tourism Jakarta bertanggung jawab terhadap seluruh fasilitas dan pelayanan selama jamaah berada di tanah suci sesuai dengan fasilitas dan pelayanan yang dibutuhkan. Semakin banyaknya calon jamaah yang akan menunaikan umroh semakin banyak pula kebutuhan informasi yang akurat dari perusahaan penyedia jasa umroh. Dengan pengolahan data yang masih konvensional diantaranya pengolahan data master jamaah, data pesanan, data paket, data sertifikat hingga pembuatan laporan selalu terjadi penumpukan dokumen, yang akan memungkinkan kesalahan pengolahan data dan saat pencarian data akan sulit ditemukan yang diperlukan merupakan hal yang menjadi kendala bagi staff pelayanan sehingga berpengaruh terhadap keterlambatan terbentuknya laporan yang akan disampaikan kepada pimpinan perusahaan. Dengan alasan itu maka diperlukan suatu sistem informasi yang dapat mengakomodir kebutuhan layanan umroh berbasis website yang memudahkan staff pelayanan dalam pengolahan data umroh. Perancangan sistem informasi ini dibuat dengan metode pengembangan sistem Model RAD (Rapid Application Development) dengan tahapan pemodelan bisnis, pemodelan data, pemodelan proses, pembuatan aplikasi, pengujian dan pergantian. Hasil dari penelitian ini dengan sistem informasi yang terkomputerisasi tidak ada lagi kerangkapan dokumen, pembuatan laporan layanan umroh lebih cepat tepat dan akurat karena menggunakan sistem komputerisasi dan kontrol data pemesanan, pembayaran dan pelunasan biaya umroh lebih mudah dilakukan dan dapat dengan mobile.
\end{abstract}

Kata kunci: layanan umroh, sistem informasi, RAD, website.

Abstract: PT. Galang Saudi Tourism Jakarta handles the types of Umrah services that are tailored to the capabilities and needs of the congregation by providing several options for Umrah packages. PT. Galang Saudi Tourism Jakarta is responsible for all facilities and services as long as the congregation is in the holy land according to the facilities and services needed. The more prospective pilgrims who will perform the Umrah, the more accurate information is needed 
from the Umrah service provider companies. With data processing that is still conventional, including processing congregation master data, order data, package data, certificate data to making reports, there is always a buildup of documents, which will allow data processing errors, and when searching for data it will be difficult to find what is needed is a problem for staff service so that it affects the delay in the formation of reports to be submitted to company leaders. For that reason, an information system is needed that can accommodate the needs of website-based Umrah services that make it easier for service staff to process Umrah data. The design of this information system is made with the RAD Model system development method (Rapid Application Development) with the stages of business modeling, data modeling, process modeling, application development, testing, and replacement. The results of this study with a computerized information system that no longer has duplicate documents, making Umrah service reports is faster, more precise, and accurate because it uses a computerized system and data control for ordering, paying, and paying Umrah fees easier to do and can be done by mobile.

Keywords: umrah services, information system, RAD, website.

\section{Pendahuluan}

Perkembangan teknologi informasi saat ini sangat pesat seiring dengan adanya kebutuhan dari aktivitas bisnis, hal ini disebabkan semakin kompleks dan semakin banyak transaksi yang harus ditangani oleh perusahaan, sehingga dalam penyelesaian masalah dengan solusi yang tepat dan pengambilan keputusan dapat dilakukan dengan cepat dan akurat. Bagi maju mudurnya dalam suatu oerganisasi sangat dipengaruhi oleh pengambilan keputusan [1]. Dengan semakin pesatnya perkembangan teknologi informasi tersebut, maka kebutuhan teknologi komputerisasi diharapkan juga semakin baik, guna menghasilkan suatu informasi yang akurat dan bermanfaat.

PT. Galang Saudi Tourism Jakarta merupakan salah satu biro perjalanan yang menangani layanan umroh ke tanah suci. PT. Galang Saudi Tourism Jakarta mempunyai beberapa paket yang dapat disesuaikan dengan kemampuan dan kebutuhan jamaah. Dengan memberikan beberapa pilihan paket umroh. PT. Galang Saudi Tourism Jakarta bertanggung jawab terhadap seluruh fasilitas dan pelayanan selama jamaah berada di tanah suci sesuai dengan fasilitas dan pelayanan yang sudah disepakati terlebih dahulu. [2]

Kebutuhan informasi sangat dibutuhkan oleh jamaah umroh baik yang masih di Indonesia atau yang sudah berangkat ke tanah suci. Informasi yang mudah didapat merupakan suatu keunggulan perusahaan, semakin mudah dan akurat informasi yang didapat oleh jamaah maka semakin tinggi kepercayaan jamaah terhadap perusahaan penyedia jasa umroh. Hal inilah salah satu yang menjadi ukuran kesuksesan perusahaan dalam meningkatkan pendapatan, dimana kepercayaan jamaah merupakan asset bagi perusahaan. Kesemuanya itu dapat dicapai dengan pembangunan suatu website yang baik.[3]

Penelitian yang dilakukan oleh [4] menjelaskan bahwa kebutuhan konsumen terhadap suatu informasi sangat penting, informasi yang cepat, akurat dan relevan merupakan tantangan yang harus dihadapi oleh setiap perusahaan untuk memaksimalkan layanan dalam memenuhi kebutuhan informasi pada pada masa sekarang saat ini.

Selain itu penelitian yang dilakukan oleh [5] menjelaskan bahwa website sebagai media pemasaran untuk menjangkau lebih banyak konsumen dengan lokasi yang lebih luas juga sistem informasi pendaftaran umroh ini di lengkapi dengan upload dokumen yang dibutuhkan, laporan penjualan paket perjalanan dalam bentuk tabel, laporan data jamaah dan periode pembayaran yang dibutuhkan oleh administrasi pada PT. Rihlah Semesta Abadi.

Penelitian yang sudah dipublikasi oleh [6] menyimpulkan bahwa dengan adanya website pada Museum Sejarah Jakarta dapat memudahkan penyebaran informasi koleksi museum, sehingga masyarakat mengetahui keberadaan koleksi dan pengolahan data koleksinya pun dapat dioleh dengan efektif dan efisien.

Permasalahan pada PT. Galang Saudi Tourism Jakarta adalah belum adanya media online yang memudahkan jamaah maupun calon jamaah untuk mendapatkan informasi paket umroh yang diadakan oleh perusahaan, kemudian pengelolaan data pada PT. Galang Saudi Tourism Jakarta masih menggunakan manual yang memungkinkan seringnya terjadi kesalahan data, kerangkapan data sampai dengan pembuatan laporan yang membutuhkan waktu yang lama. 
Tujuan penelitian ini merancang sistem informasi yang memudahkan user dalam pengelolaan data jamaah umroh, pengelolaan data keuangan, pengelolaan data manasik sampai dengan pembuatan laporan disamping website merupakan sarana promosi bagi perusahaan yang memudahkan penyampaian informasi baik untuk calon jamaah maupun jamaah yang sudah pernah menggunakan layanan jasa PT. Galang Saudi Tourism Jakarta.

\section{Metode Penelitian}

\section{Metode Pengembangan Sistem}

Penelitian ini menggunakan metode Rapid Application Development (RAD). Tahapan atau langkah yang harus dilaksanakan diantaranya [7]: a) pemodelan bisnis, pemodelan bisinis pada rancangan pada website ini adanya kebutuhan yaitu informasi layanan umroh pada PT. Galang Saudi Tourism Jakarta seperti input data paket, input data jamaah, input data pemesanan oleh jamaah, input data pembayaran sampai dengan hasil pengolahan yaitu jadwal manasik, jadwal keberangkatan, pembuatan sertifikat hingga laporan layanan umroh yang dapat dilihat oleh direktur PT. Galang Saudi Tourism Jakarta, b) pemodelan data, tahap pemodelan data dilakukan dengan pembuatan dokumen masukan dan dokumen keluaran yang ada pada sistem ini, c) pemodelan proses, dalam merancang website ini peneliti, mengklasifikasikan dua tools yaitu tools system dan tools aplication, pada tools system memakai Unified Modelling Language (UML), terdiri dari Diagram Use Case, Diagram Activity, Class Model/Class Diagram dan Sequence Diagram. Untuk databasenya menggunakan Entity Relation Diagram (ERD) dan Logical Record Stucture (LRS), d) pembuatan aplikasi, coding program atau kode program yang digunakan adalah PHP dengan database MySQ yang dibundle aplikasi CMS Xampp, e) pengujian dan pergantian, testing profram atau pengetasan program apakah valid atau tidak, metode yang tepat adalah blackbox, karena dapat dengan mudah menelusuri penyebab kesalahan. Sebelum website di launching ke masyarakat atau jamaah, serangkaian blackbox testing dilakanakan terlebih dahulu. Kegiatan ini diterapkan pada semua komponen yang ada agara kesalahan dapat diminimalisir.

\section{Prosedur Sistem Berjalan Sistem}

Sebelum masuk ke permodelan sistem, maka dibuat terlebih dahulu urutan prosedur berjalan sistem layanan umroh pada PT. Galang Saudi Tourism Jakarta saat ini dimana: a) proses pendaftaran umroh, staff pelayanan menerima jamaah yang ingin mendaftar Umroh. Tahap pertama menawarkan paket yang ada beserta penjelasannya. Pemberian formulir kosng rangkap dua kepada calon jamaah yang berminat. Calon jamaah mengisi dan menandatangani formulir tersebut. Diserahkan kembali kepada staff pelayanan. Proses pengecekan dilakukan, Jika masih kurang dikembalikan kepada calon jamaah untuk dilengkapi. Bagi yang sudah valid atau lengkap, staff pelayanan melakukan verifikasi pendaftaran. Formulir pertama diserahkan ke calon jamaah. Formulir kedua disimpan untuk diarsipkan, b) proses pembayaran biaya umroh/pembayaran DP atau tanda jadi, minimal pembayaran biaya umroh/DP umroh di PT. Galang Saudi Tourism Jakarta sebanyak 50\%. Pembayarannya harus dilakukan ketika calon jamaah umroh telah melakukan pendaftaran terlebih dahulu. Staff pelayanan memberikan informasi biaya yang harus dibayarkan. Setelah mengetahui jumlah biaya yang harus dibayar, pendaftar atau calon jamaah bisa langsung melakukan pembayaran via transfer ke nomor rekening yang sudah disediakan oleh PT. Galang Saudi Tourism Jakarta. Stuk/bukti transfer yang didapat dari bank atau Automatic Teller Machine (ATM) yang didapat ketika melakukan transfer diberikan ke staff pelayanan sebagai bukti bahwa pendaftar atau calon jamaah tersebut sudah melakukan transfer ke PT. Galang Saudi Tourism Jakarta. Selanjutnya, staff pelayanan membuat invoice pembayaran rangkap dua, invoice pertama diberikan ke pendaftar atau calon jamaah dan invoice kedua sebagai arsip dan disimpan oleh staff pelayanan, c) proses pembayaran biaya umroh/pelunasan, pelunasan dilakukan ketika pendaftar atau calon jamaah sudah melakukan pendaftaran dan pembayaran uang muka/DP atau tanda jadi. Calon jamaah akan memberikan formulir pendaftaran atau invoice pembayaran DP, lalu staff pelayanan mencocokkan data sisa tagihan yang dimiliki calon jamaah dan memberikan informasi tentang tagihan yang harus dibayar. Setelah mengetahui jumlah tagihan yang harus dibayar, pendaftar atau jamaah bisa langsung melakukan transfer ke nomor rekening yang sudah disediakan oleh PT. Galang Saudi Tourism Jakarta. Bukti transfer/struk yang didapat dari bank atau ATM yang didapat ketika melakukan transfer ke PT. Galang Saudi Tourism Jakarta diberikan ke staff 
pelayanan sebagai bukti bahwa pendaftar atau calon jamaah tersebut sudah melakukan transfer ke PT. Galang Saudi Tourism Jakarta. Selanjutnya, staff pelayanan membuat kwitansi pembayaran pelunasan rangkap dua, kwitansi pertama diberikan ke pendaftar atau calon jamaah dan kwitansi kedua oleh staff pelayanan disimpan sebagai arsip, d) proses penjadwalan peserta manasik umroh, proses ini dimulai ketika general manager menentukan semua yang dibutuhkan selama manasik umroh, seperti tempat, waktu dan kuota jamaah manasik. Selanjutnya, general manager memberi instruksi ke staff pelayanan untuk memesan tempat, konsumsi dan menyiapkan perlengkapan seperti Alat Tulis Kantor (ATK), proyektor dan lainlain. Sedangkan general manager yang akan memesan pembimbing manasik dan materi yang akan diberikan oleh pembimbing untuk peserta manasik umroh. Setelah itu, semua yang dibutuhkan untuk manasik umroh direkap oleh general manager menjadi sebuah jadwal manasik umroh. General manager membuat list jamaah yang menjadi peserta manasik umroh. List tersebut diberikan ke staff pelayanan untuk diteruskaninformasinya ke peserta. Seminggu sebelum acara manasik umroh tersebut berlangsung, staff pelayanan melakukan konfirmasi ulang ke pendaftar melalui telepon dan pendaftar akan memberikan konfirmasi kehadiran, e) proses pembuatan laporan, proses pembuatan laporan terdiri dari pembuatan dokumen laporan pendaftaran, laporan pembayaran, laporan manasik umroh pembuatan laporan paket. Laporan tersebut nantinya akan ditunjukkan kepada direktur PT. Galang Saudi Tourism Jakarta.

\section{Hasil dan Pembahasan}

Pendekatan yang digunakan adalah object oriented, dengan UML (Unified Modelling Language) tools serta metode Model Rapid Application Development (RAD). Berikut langkahlangkah rancangannya:

\section{Pemodelan Bisnis}

Untuk memperbaiki sistem yang ada atau berjalan, maka disusulkan dengan penggambaran use case diagram dan scenario use case [8]. Kebutuhan pengguna merupakan tolok ukur dalam pembuatan sebuah perangkat lunak atau aplikasi. Terdapat dua pengguna yang saling bekerja sama dan bersinergi, yaitu General Manager (GM) dan staff pelayanan. Berikut adalah kebutuhan informasi dari masing-masing pengguna: a) skenario kebutuhan general manager: 1) login kedalam sistem, 2) mengolah master paket, master user, 3) melihat master jamaah, 4) melihat pemesanan dan pembayaran, 5) melihat laporan paket, 6) melihat laporan pembayaran, 7) melihat laporan data jamaah, 8) mengelola laporan data user, dan 9) melakukan logout dan, b) skenario kebutuhan staff pelayanan: 1) melakukan login kedalam sistem, 2) mengelola master jamaah, 3) mengelola pemesanan dan pembayaran, 4) mengelola laporan data jamaah, 5) mengelola laporan pemesanan, 6) mengelola laporan pembayaran, 7) mengelola sertifikat umroh, 8) melakukan logout. Setiap pengguna harus login terlebih dahulu untuk dapat mengakses aplikasi ini dengan memasukkan username dan password, ini dimaksudkan agar keamanan data setiap pengguna dapat terjaga. Setelah selesai Pengguna harus melakukan logout.

\section{Pemodelan Data}

Pemodelan data dijelaskan dengan dokumen-dokumen yang harus disediakan sebelum dilakukan pemodelan proses, dokumen yang diperlukan diantaranya: a) rancangan dokumen masukan (Input): 1) formulir pendaftaran, 2) berkas persyaratan, 3) struk pembayaran DP, 4) struk pembayaran pelunasan, dan b) spesifikasi dokumen keluaran: 1) invoice pembayaran DP, 2) invoice pembayaran pelunasan, 3) list peserta manasik umroh, 4) laporan, 5) sertifikat.

\section{Pemodelan Proses}

Untuk memudahkan implementasi sistem dibuat gambaran yang jelas tentang aplikasi yang akan dibangun [9]. Sistem informasi layanan umroh digambarkan dengan empat diagram yang digunakan diantaranya diagram use case, diagram activity, ERD, Logical Record Structure (LRS), Diagram Class dan Diagram Sequance. Diagram use case merupakan penggambaran secara ringkas apa saja yang bisa dilakukannya, oleh General Manager dan Staff Pelayanan. Diagram use case untuk General Manager dijelaskan pada gambar 1. 
BINA INSANI ICT JOURNAL ISSN: 2355-3421 (Print) ISSN: 2527-9777 (Online); 1 - 11



Sumber: Hasil Penelitian (2021)

Gambar 1. Diagram Use Case General Manager

Diagram use case untuk staff pelayanan dijelaskan pada gambar 2.

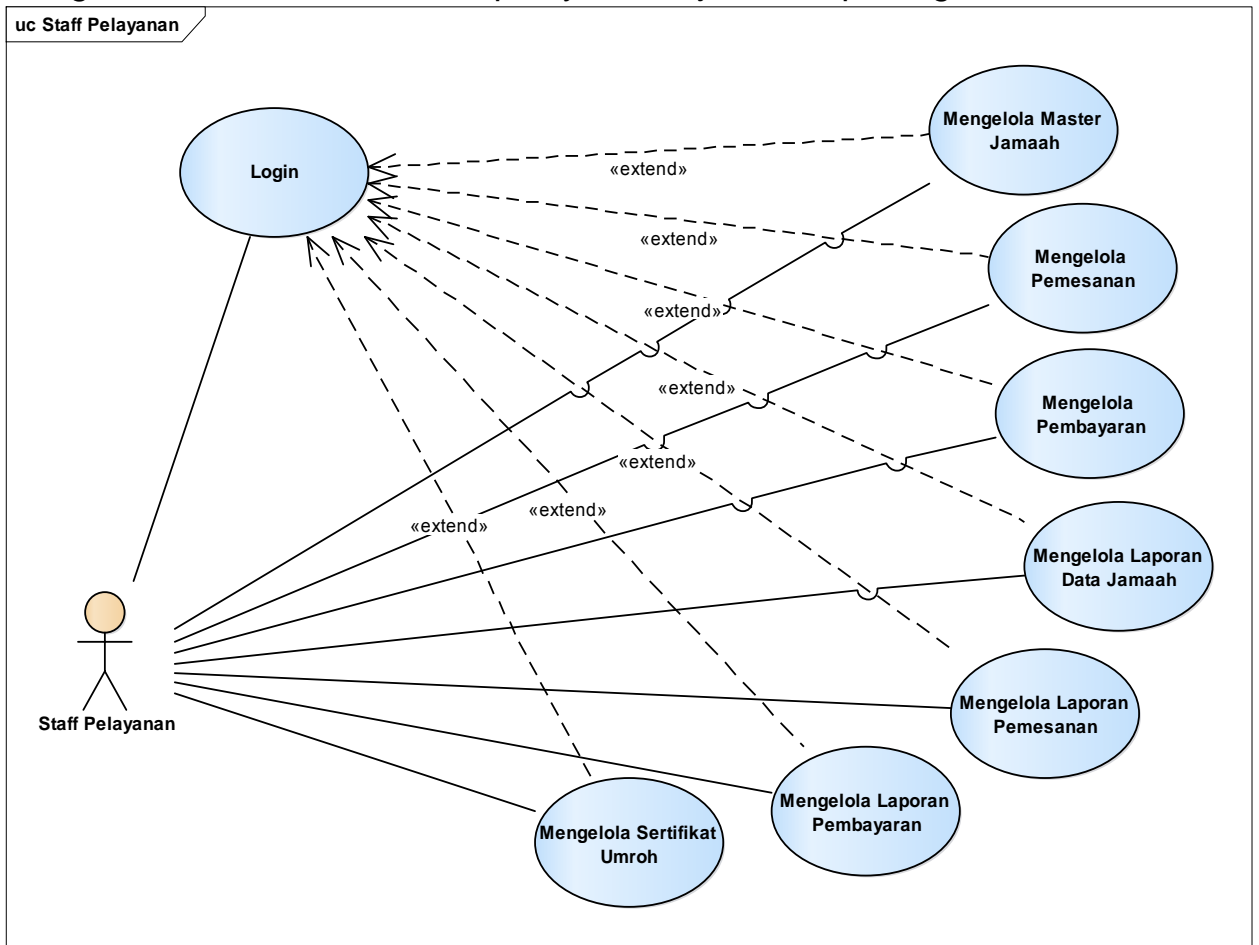

Sumber: Hasil Penelitian (2021)

Gambar 2. Diagram Use Case Staff Pelayanan

Diagram activity merupakan penggambaran workflow (alur kerja) atau kegiatan dari proses bisnis. Dalam hal ini yang ditampilkan hanya Login General Manager dijelaskan pada gambar 3. 


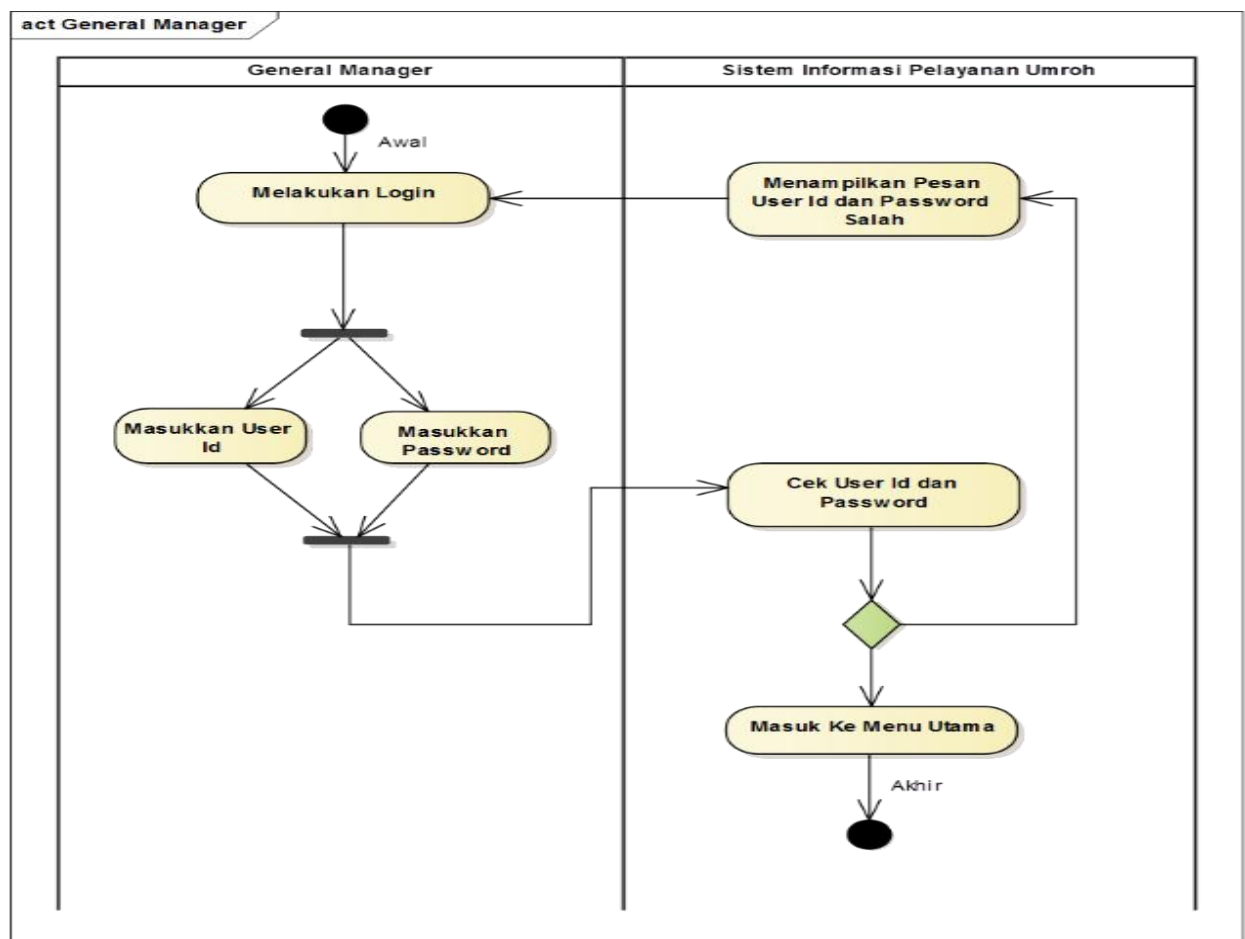

Sumber: Hasil Penelitian (2021)

Gambar 3. Diagram Aktivitas Login General Manager

Entity Relationship Diagram (ERD), penggambaran model atau rancangan database, dilakukan dengan menggambarkan data yang memiliki relasi dalam bentuk sebuah desain. Berikut ERD dari rancangan sistem layanan umroh pada PT. Galang Saudi Tourism Jakarta dijelaskan pada gambar 4.

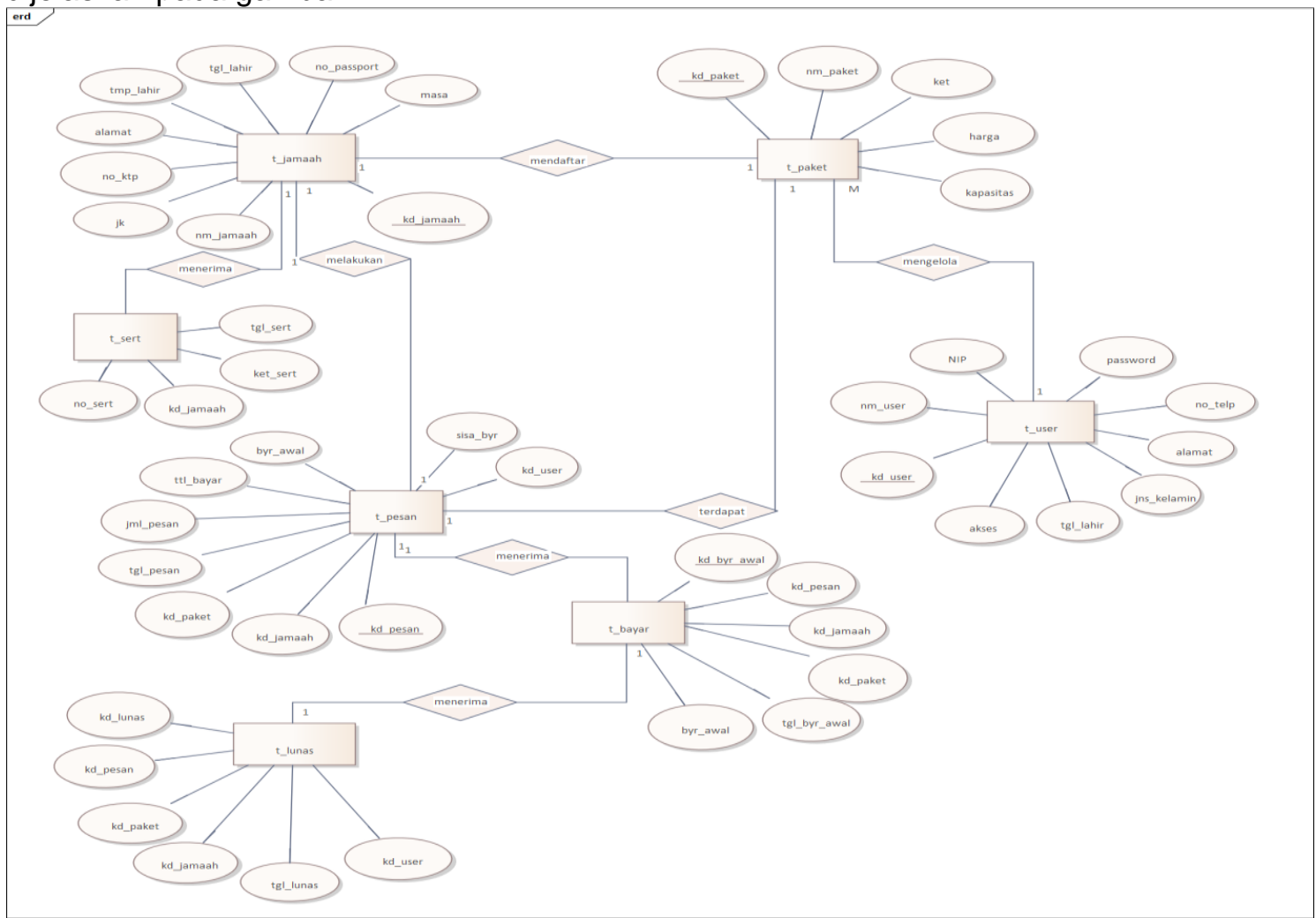

Sumber: Hasil Penelitian (2021)

Gambar 4. Entity Relationship Diagram (ERD) 
Logical Record Struktur (LRS), merupakan representasi dari struktur record-record pada tabel-tabel yang terbentuk dari hasil relasi antar himpunan entitas digambarkan pada LRS, berikut ini LRS dari rancangan sistem layanan umroh pada PT. Galang Saudi Tourism Jakarta dijelaskan pada gambar 5 .

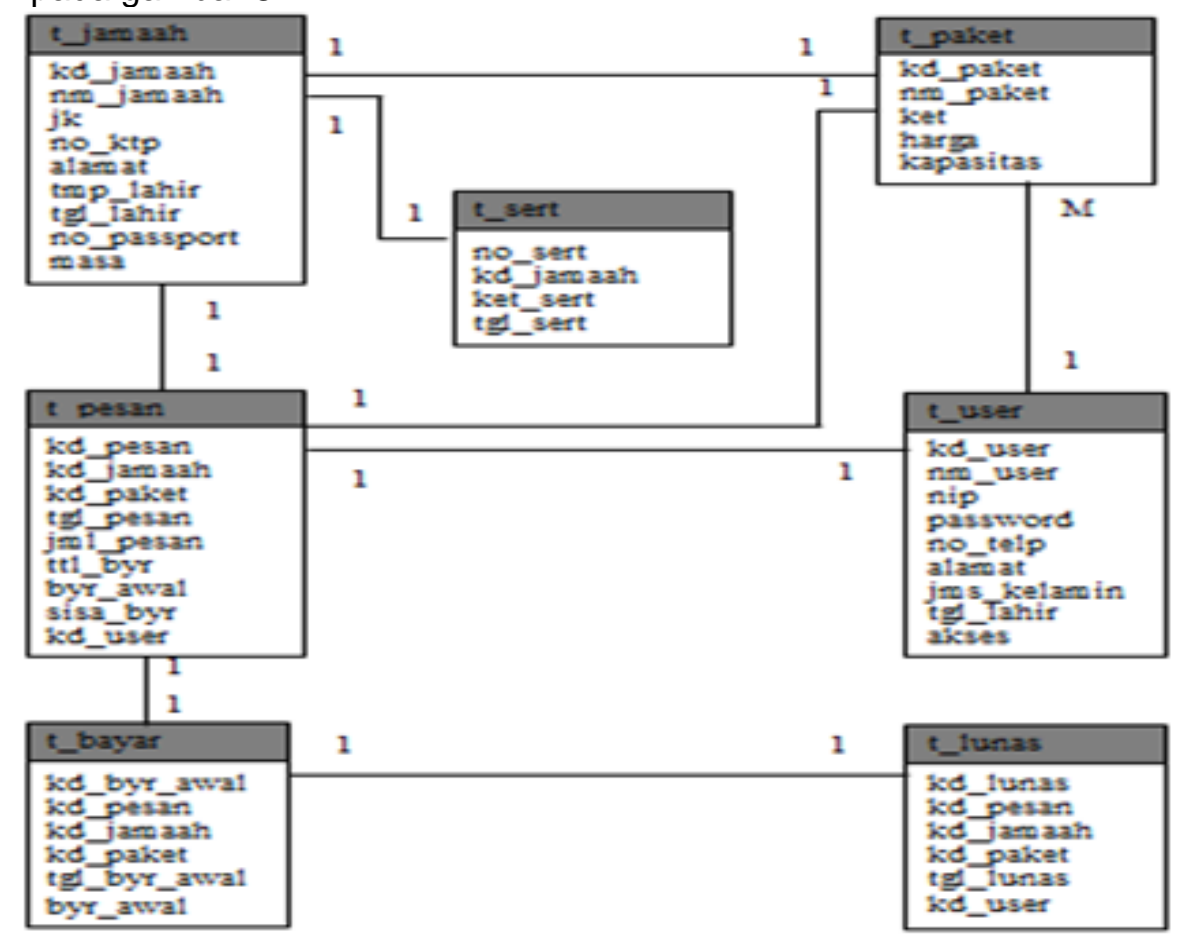

Sumber: Hasil Penelitian (2021)

Gambar 5. Logical Record Struktur (LRS)

Sequence diagram menggambarkan kolaborasi dinamis antara sejumlah object yang berguna untuk menunjukkan rangkaian pesan yang dikirim antara object juga interaksi antara object. Pada rancangan sistem layanan umroh pada PT. Galang Saudi Tourism Jakarta ini berikut sequence diagramnya untuk menu General Manager dijelaskan pada gambar 6 .

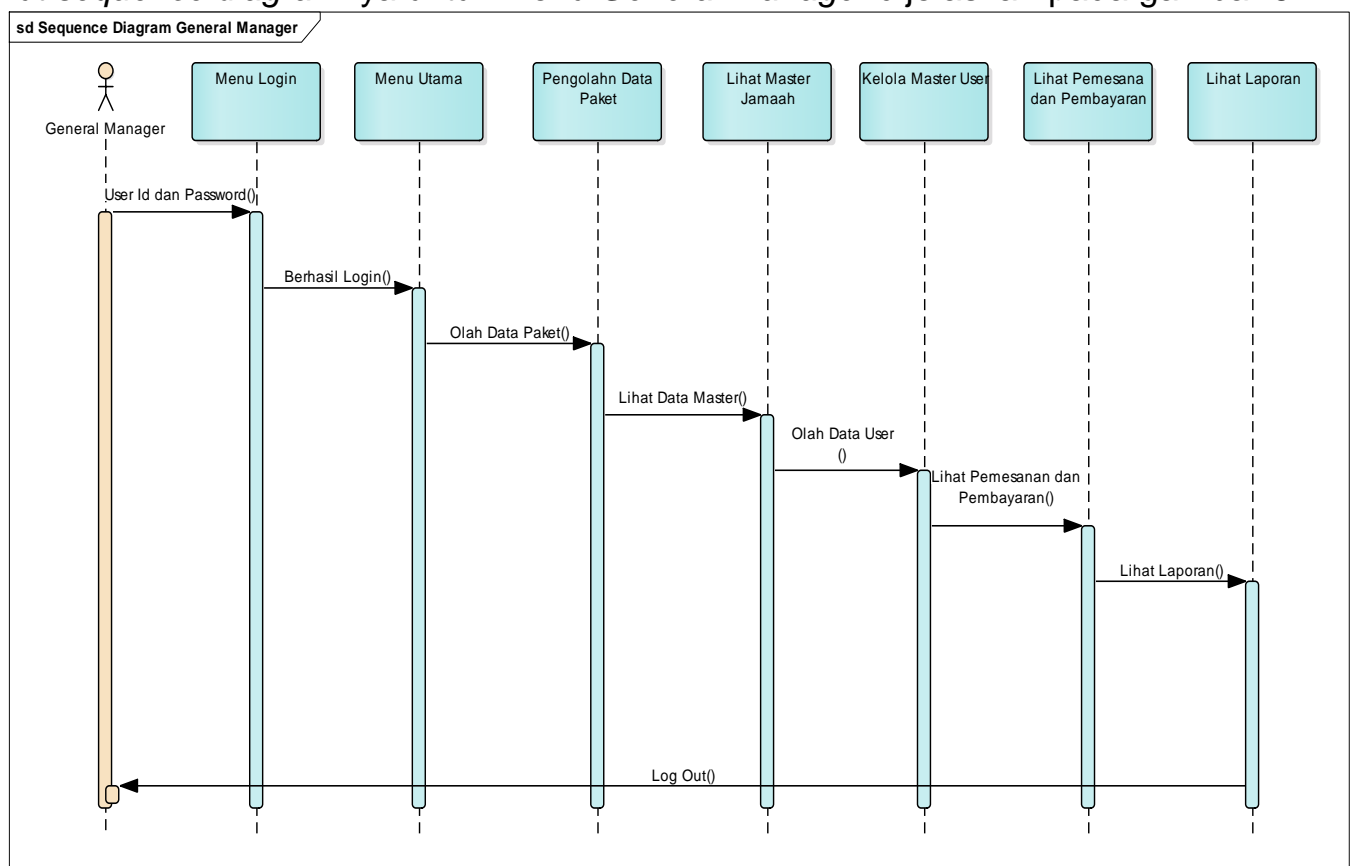

Sumber: Hasil Penelitian (2021)

Gambar 6. Sequence Diagram Menu General Manager 
Sequence Diagram untuk menu staff pelayanan dijelaskan pada gambar 7.

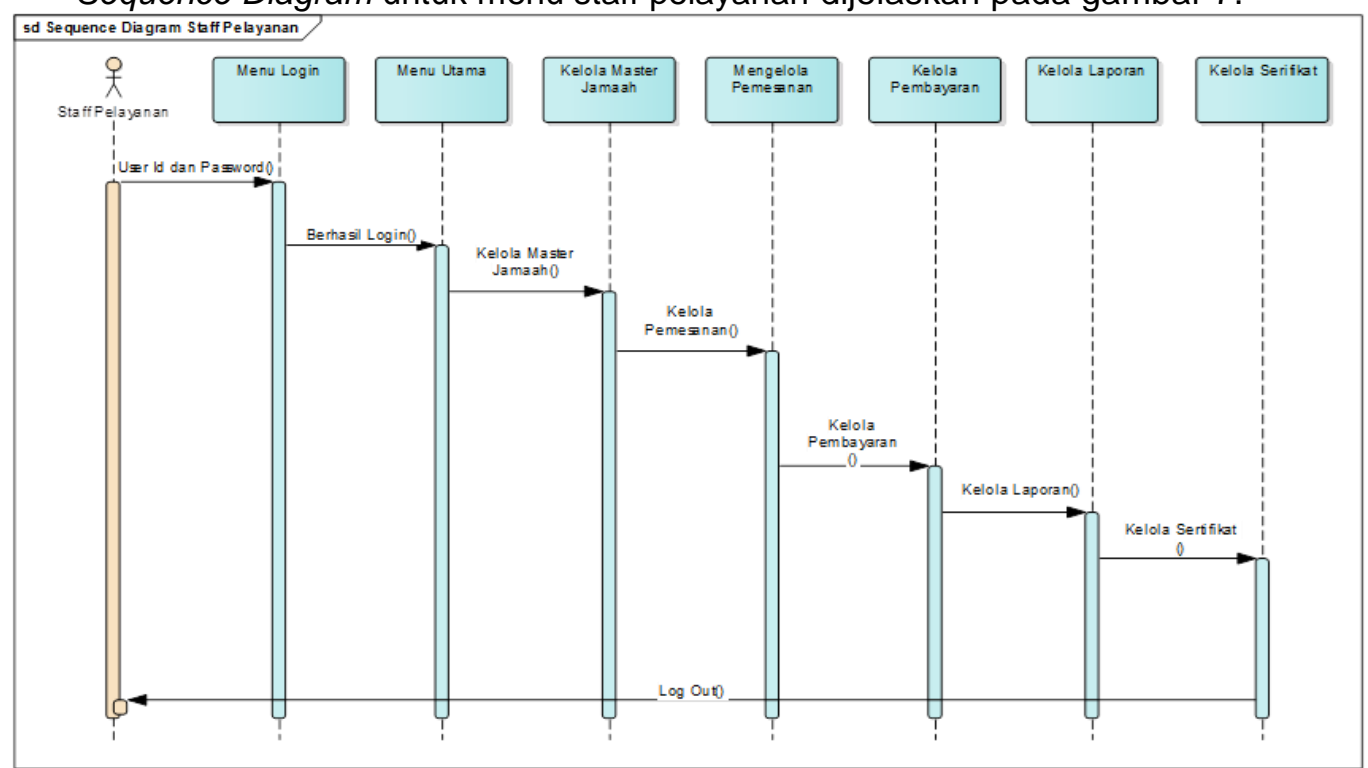

Sumber: Hasil Penelitian (2021)

Gambar 7. Sequence Diagram Menu Staff Pelayanan

Class Model/Class Diagram merupakan suatu set objek yang memiliki atribut dan perilaku yang sama, Class kadang disebut object class. [10]. Pada rancangan sistem layanan umroh pada PT. Galang Saudi Tourism Jakarta ini berikut class model/class diagramnya dijelaskan pada gambar 8 .

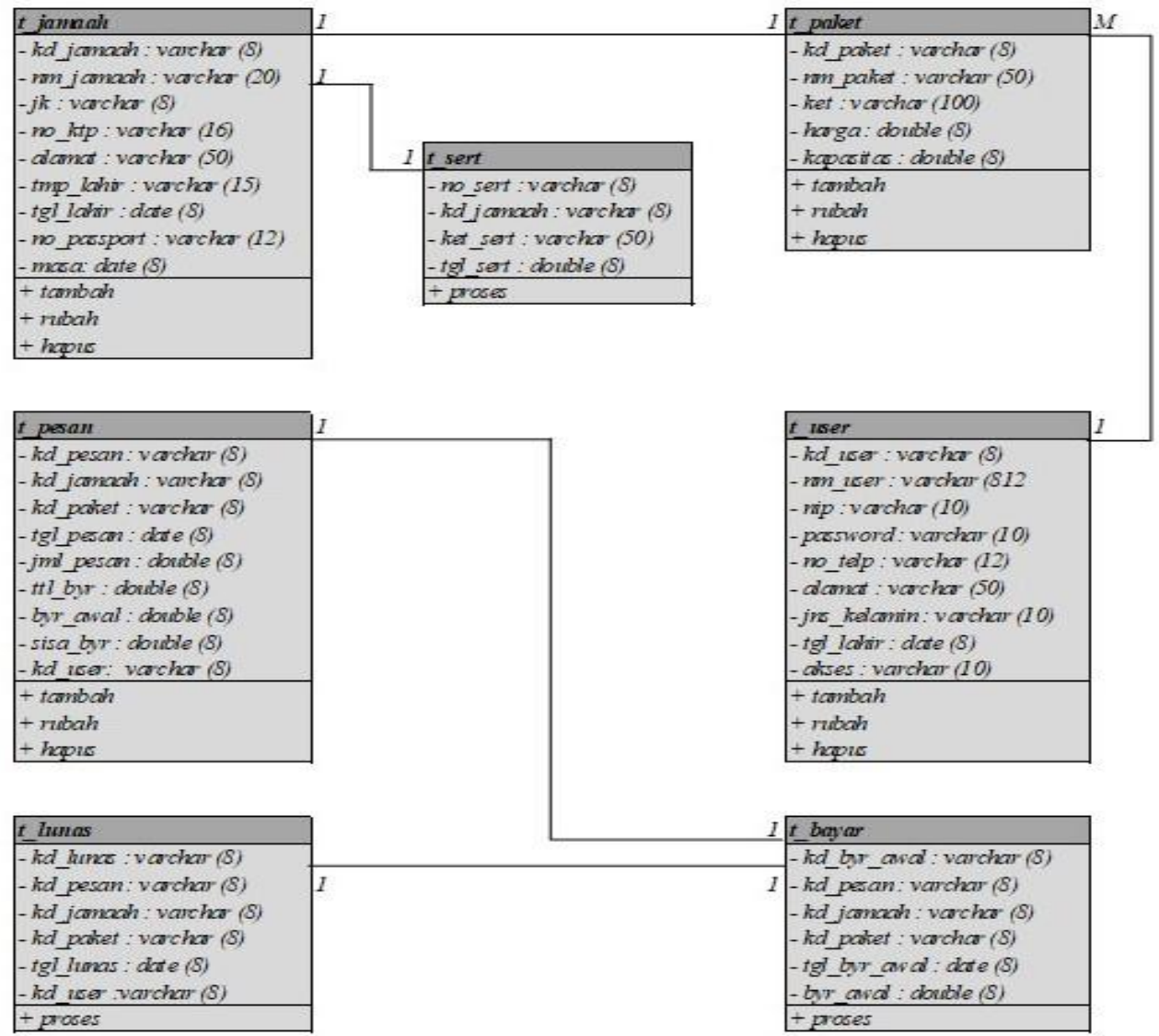

Sumber: Hasil Penelitian (2021)

Gambar 8. Class Model/Class Diagram 
BINA INSANI ICT JOURNAL ISSN: 2355-3421 (Print) ISSN: 2527-9777 (Online); 1 - 11

\section{Pembuatan Aplikasi}

Tahap ini merupakan implementasi bahasaa pemrograman menjadi form yang dibutuhkan dalam pembuatan aplikasi sistem layanan umroh pada PT. Galang Saudi Tourism Jakarta diantaranya: Form Login dijelaskan pada gambar 9.

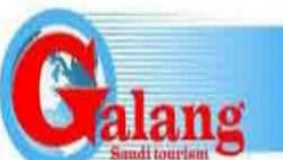

\section{PI. GALANG SADDI TOURISM}

Penyelenggara Haij \& Umroh No. 668 Tahun 2017

\section{SISTEM INFORMASI LAYANAN UMROH}

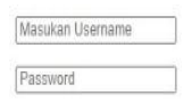

Login

Sumber: Hasil Penelitian (2021)

Gambar 9. Form Login

Form untuk Menu General Manager dijelaskan pada gambar 10.

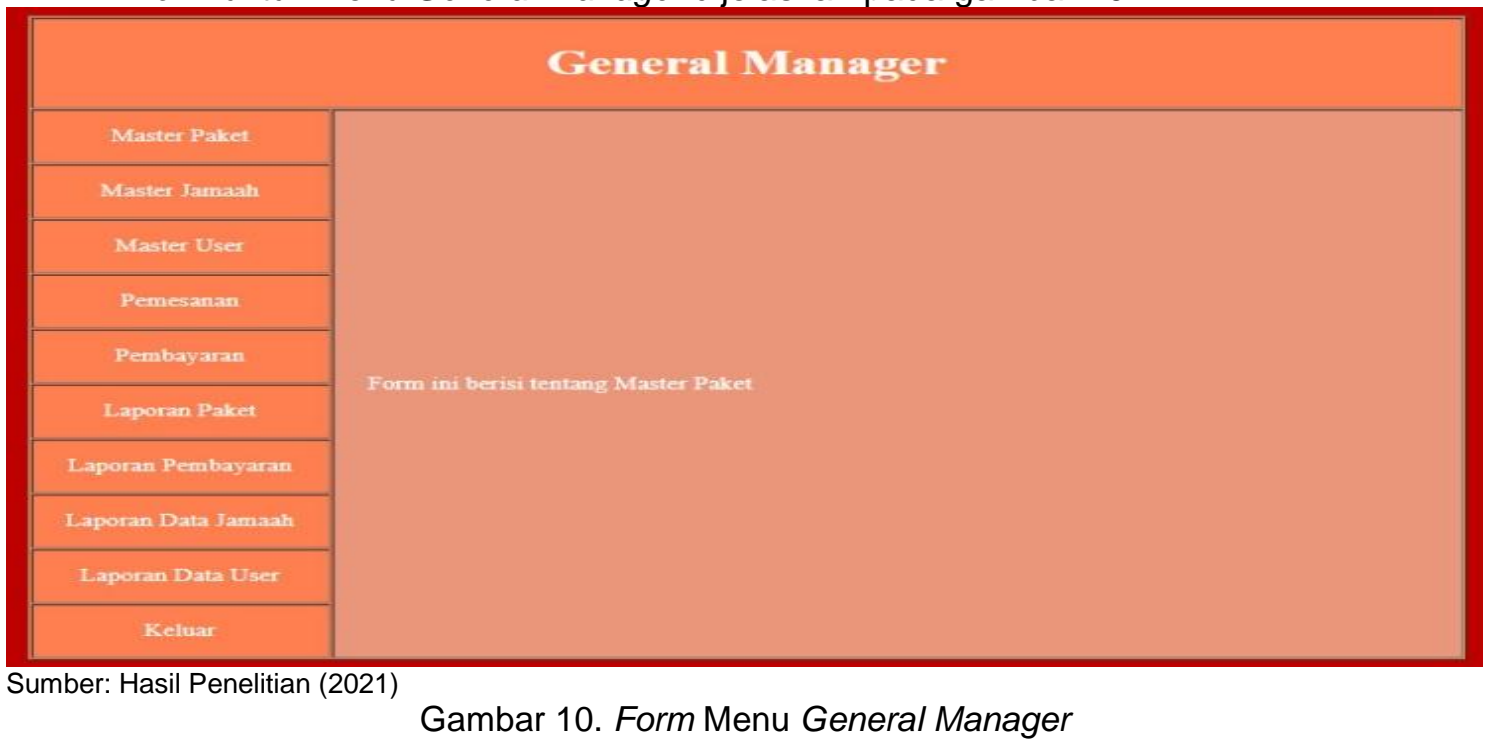

Form Menu Staff Pelayanan dijelaskan pada gambar 11.

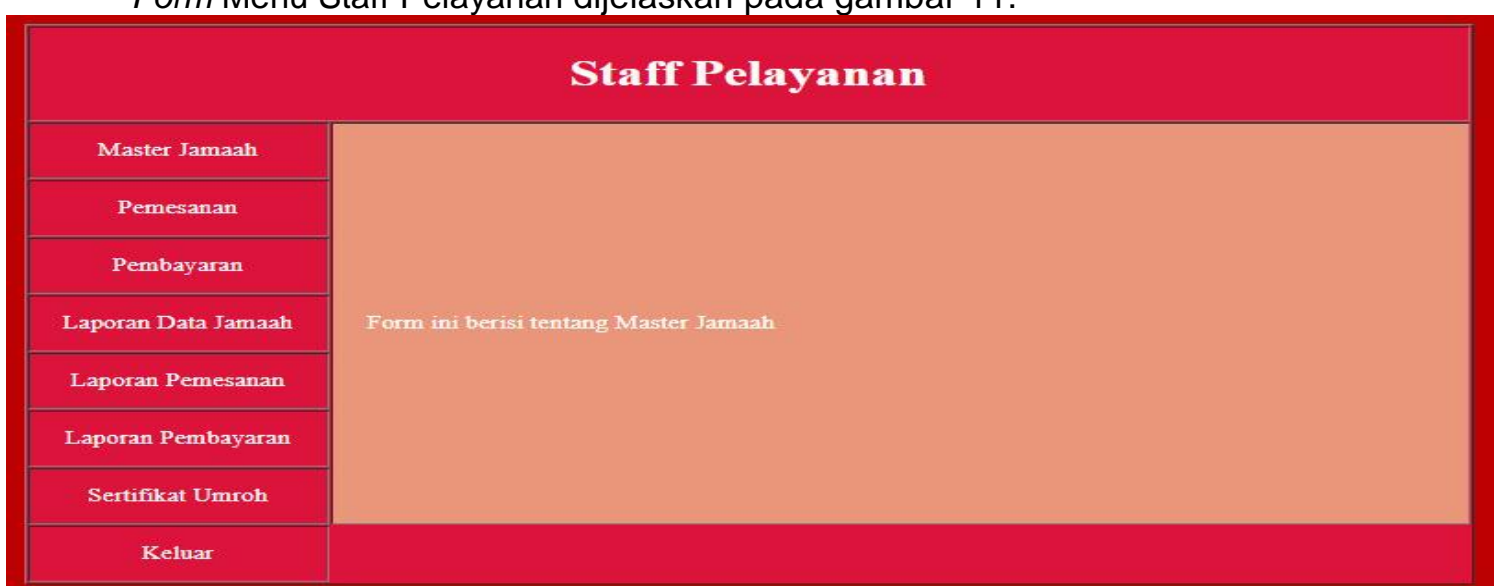

Sumber: Hasil Penelitian (2021)

Gambar 11. Form Menu Staff Pelayanan 


\section{Pengujian}

Pengujian program dilakukan dengan testing terhadap form login general manager dan login staff pelayanan. Pengujian terhadap halaman form login untuk General Manager dijelaskan pada tabel 1.

Tabel 1. Hasil Uji Black Box Testing Form Login General Manager

\begin{tabular}{|c|c|c|c|c|c|}
\hline No & Skenario Pengujian & Test Case & $\begin{array}{l}\text { Hasil yang } \\
\text { diharapkan }\end{array}$ & Hasil Pengujian & Kesimpulan \\
\hline 1 & $\begin{array}{l}\text { Username dan } \\
\text { passwoar tidak diisi } \\
\text { kemudian klik } \\
\text { tombol login }\end{array}$ & $\begin{array}{l}\text { Username: (kosong) } \\
\text { Password: (kosong) }\end{array}$ & $\begin{array}{l}\text { Sistem akan menolak } \\
\text { akses user dan } \\
\text { kembali ke menu } \\
\text { login. }\end{array}$ & $\begin{array}{l}\text { Sesuai } \\
\text { harapan }\end{array}$ & Valid \\
\hline 2 & $\begin{array}{l}\text { Mengetikkan } \\
\text { Username dan } \\
\text { password } \\
\text { tidak diisi kemudian } \\
\text { klik tombol login }\end{array}$ & $\begin{array}{l}\text { Username: } \\
\text { general_manager } \\
\text { Password: (kosong) }\end{array}$ & $\begin{array}{l}\text { Sistem akan menolak } \\
\text { akses user dan } \\
\text { kembali ke menu } \\
\text { login. }\end{array}$ & $\begin{array}{l}\text { Sesuai } \\
\text { harapan }\end{array}$ & Valid \\
\hline 3 & $\begin{array}{l}\text { Username tidak diisi } \\
\text { dan password diisi } \\
\text { kemudian klik } \\
\text { tombol login }\end{array}$ & $\begin{array}{l}\text { Username: (kosong) } \\
\text { Password: ga12345 }\end{array}$ & $\begin{array}{l}\text { Sistem akan menolak } \\
\text { akses user dan } \\
\text { kembali ke menu } \\
\text { login. }\end{array}$ & $\begin{array}{l}\text { Sesuai } \\
\text { harapan }\end{array}$ & Valid \\
\hline 4 & $\begin{array}{l}\text { Mengetik Username } \\
\text { dengan benar dan } \\
\text { Mengetikkan salah } \\
\text { pada Password dan } \\
\text { kemudian klik tombol } \\
\text { login }\end{array}$ & $\begin{array}{l}\text { Username: } \\
\text { general_manager } \\
\text { (benar) } \\
\text { Password: ga1234 } \\
\text { (salah) }\end{array}$ & $\begin{array}{l}\text { Sistem akan menolak } \\
\text { akses user dan } \\
\text { kembali ke menu } \\
\text { login. }\end{array}$ & $\begin{array}{l}\text { Sesuai } \\
\text { harapan }\end{array}$ & Valid \\
\hline 5 & $\begin{array}{l}\text { Mengetikkan } \\
\text { Username dengan } \\
\text { benar dan password } \\
\text { dengan benar } \\
\text { kemudian } \\
\text { klik tombol login }\end{array}$ & $\begin{array}{l}\text { Username: } \\
\text { general_manager } \\
\text { (benar) } \\
\text { Password: ga1234 } \\
\text { (benar) }\end{array}$ & $\begin{array}{l}\text { Sistem menerima } \\
\text { akses login dan } \\
\text { kemudian masuk ke } \\
\text { halaman general } \\
\text { manager. }\end{array}$ & $\begin{array}{l}\text { Sesuai } \\
\text { harapan }\end{array}$ & Valid \\
\hline
\end{tabular}

Pengujian terhadap halaman form login untuk staff pelayanan dijelaskan pada tabel 2 .

Tabel 2. Hasil Uji Black Box Testing Form Login Staff Pelayanan

\begin{tabular}{|c|c|c|c|c|c|}
\hline No & Skenario Pengujian & Test Case & $\begin{array}{l}\text { Hasil yang } \\
\text { diharapkan }\end{array}$ & Hasil Pengujian & Kesimpulan \\
\hline 1 & $\begin{array}{l}\text { Username dan } \\
\text { passwoar tidak diisi } \\
\text { kemudian klik } \\
\text { tombol login }\end{array}$ & $\begin{array}{l}\text { Username: (kosong) } \\
\text { Password: (kosong) }\end{array}$ & $\begin{array}{l}\text { Sistem akan } \\
\text { menolak akses user } \\
\text { dan kembali ke } \\
\text { menu login. }\end{array}$ & $\begin{array}{l}\text { Sesuai } \\
\text { harapan }\end{array}$ & Valid \\
\hline 2 & $\begin{array}{l}\text { Mengetikkan Username } \\
\text { dan password } \\
\text { tidak diisi kemudian } \\
\text { klik tombol login }\end{array}$ & $\begin{array}{l}\text { Username: } \\
\text { staff_pelayanan } \\
\text { Password: (kosong) }\end{array}$ & $\begin{array}{l}\text { Sistem akan } \\
\text { menolak akses user } \\
\text { dan kembali ke } \\
\text { menu login. }\end{array}$ & $\begin{array}{l}\text { Sesuai } \\
\text { harapan }\end{array}$ & Valid \\
\hline 3 & $\begin{array}{l}\text { Username tidak diisi dan } \\
\text { password diisi } \\
\text { kemudian klik } \\
\text { tombol login }\end{array}$ & $\begin{array}{l}\text { Username: (kosong) } \\
\text { Password: sa12345 }\end{array}$ & $\begin{array}{l}\text { Sistem akan } \\
\text { menolak akses user } \\
\text { dan kembali ke } \\
\text { menu login user. }\end{array}$ & $\begin{array}{l}\text { Sesuai } \\
\text { harapan }\end{array}$ & Valid \\
\hline 4 & $\begin{array}{l}\text { Mengetik Username } \\
\text { dengan benar dan } \\
\text { Mengetikkan salah } \\
\text { pada Password dan } \\
\text { kemudian klik tombol } \\
\text { login }\end{array}$ & $\begin{array}{l}\text { Username: } \\
\text { staff_pelayanan } \\
\text { (benar) } \\
\text { Password: sa1234 } \\
\text { (salah) }\end{array}$ & $\begin{array}{l}\text { Sistem akan } \\
\text { menolak akses user } \\
\text { dan kembali ke } \\
\text { menu login user. }\end{array}$ & $\begin{array}{l}\text { Sesuai } \\
\text { harapan }\end{array}$ & Valid \\
\hline 5 & $\begin{array}{l}\text { Mengetikkan Username } \\
\text { dengan benar dan } \\
\text { password } \\
\text { dengan benar kemudian } \\
\text { klik tombol login }\end{array}$ & $\begin{array}{l}\text { Username: } \\
\text { staff_pelayanan } \\
\text { (benar) } \\
\text { Password: sa1234 } \\
\text { (benar) }\end{array}$ & $\begin{array}{l}\text { Sistem menerima } \\
\text { akses login dan } \\
\text { kemudian masuk ke } \\
\text { halaman user. }\end{array}$ & $\begin{array}{l}\text { Sesuai } \\
\text { harapan }\end{array}$ & Valid \\
\hline
\end{tabular}

\section{Kesimpulan}

Dapat dilihat dari pembahasan perancangan sistem informasi layanan umroh pada PT.

Galang Saudi Tourism Jakarta penulis menyimpulkan dengan sistem informasi yang terkomputerisasi tidak ada lagi kerangkapan dokumen, pembuatan laporan layanan umroh lebih 
cepat tepat dan akurat karena menggunakan sistem komputerisasi, kontrol data pemesanan, pembayaran dan pelunasan biaya umroh lebih mudah dilakukan dan dapat dengan mobile. Selain itu penyampaian informasi kepada jamaah maupun calon jamah lebih cepat, tepat dan akurat yang akan meningkatkan kinerja perusahaan.

\section{Referensi}

[1] H. Anwar, "Proses Pengambilan Keputusan untuk Mengembangkan Mutu Madrasah," Nadwa, vol. 8, no. 1, p. 37, 2014, doi: 10.21580/nw.2014.8.1.569.

[2] A. Syafi'i, "Perancangan Sistem Informasi Layanan Umroh Pada PT. Galang Saudi Tourism Jakarta Berbasis Website," Unversitas Bina Sarana informatika, 2020.

[3] Z. Munawaroh, M. Mudhofi, and D. Susanto, "Efektivitas Sistem Informasi Dan Komputerisasi Haji Terpadu (Siskohat) Dalam Penyelenggaraan Ibadah Haji," J. IImu Dakwah, vol. 35, no. 2, p. 225, 2017, doi: 10.21580/jid.v35i2.1608.

[4] I. R. Rahnatillah and A. B. Hikmah, "Perancangan Sistem Informasi Pelayanan Administrasi Data Umroh (Studi Kasus: PT. Utsmaniyyah Hannien Tour Tasikmalaya)," IJCIT, vol. 3, no. 1, pp. 9-17, 2018.

[5] Suparni and S. Budi, "Rancang Bangun Web Pendaftaran Umroh Pada PT. Rihlah Semesta Abadi Cibubur," Indones. J. Netw. Secur., vol. 7, no. 1, pp. 19-25, 2018.

[6] B. Santoso and B. O. Lubis, "Aplikasi Peminjaman dan Pengembalian Koleksi Museum Sejarah Jakarta Berbasis pada Dinas Pariwisata dan Kebudayaan DKI Jakarta," in Sintak, pp. 145-157, 2019.

[7] R. A. Sukamto and M. Shalahuddin, Rekayasa Perangkat Lunak Terstruktur dan Berorientasi Objek Edisi Revisi. Bandung: Informatika, 2018.

[8] I. Y. M. Napitupulu and S. Muryani, "Rancang Bangun Sistem Informasi Penjualan Perabotan Pada CV. Evamas," J. Paradig., vol. 3, no. 2, pp. 76-93, 2018, doi: 10.31294/p.v20i2.3838.

[9] A. Taufik, A. Charistian, and T. Asra, "Perancangan Sistem Informasi Penjualan Peralatan Kesehatan Dengan Metode Waterfall," J. Tek. Komput., vol. V, no. 1, pp. 135-138, 2019, doi: 10.31294/jtk.v4i2.

[10] Suendri, "Implementasi Diagram UML (Unified Modelling Language) Pada Perancangan Sistem Informasi Remunerasi Dengan Database Oracle (Studi Kasus: UIN Sumatera Utara Medan)," J. IImu Komput. dan Inform., vol. 3, no. 1, pp. 1-9, 2018. 